\title{
Whose Talk is Worth More? A Case Study into Questioning Techniques of Native and Non-Native English-Speaking Teachers
}

Received: 18/08/2019; Accepted: 09/12/2019

\begin{abstract}
Although the native/non-native speaking teacher dichotomy has stirred up ample scholarly consideration and debate in the field of English language teaching, insufficient attention has been devoted to the interactional features that characterize teacher talk, primarily teachers' questioning behavior. This study sought to determine the extent to which native and non-native English-speaking teachers diverge in terms of the different types of questions they employ in their classes. Accordingly, eight classes of a native and a non-native speaking teacher at the department of English of Constantine Teachers' College, Algeria, were audio recorded, transcribed and analyzed according to the different types of questions. The analysis of the results reveals that the native-speaking teacher is more inclined toward promoting a genuine classroom interaction by employing more procedural and referential questions along with an extensive use of comprehension checks, whereas the non-native speaking teacher tended to foster students' participation through an extensive use of display and convergent questions combined with an abundance of clarification requests and confirmation checks.
\end{abstract}

Keywords: Classroom interaction, teacher talk, questioning strategies, native, non-native teachers.
Fadhila Hadjeris ${ }^{1 *}$

\section{Pr. Sarah Merrouche ${ }^{2}$}

1Department of letters and English Language

University of Frères

Mentouri Constantine

Algeria

2 Department of English

University of Larbi Ben

M'hidi, Algeria

\section{Résumé}

Bien que la dichotomie entre enseignants de langue maternelle et non autochtone a suscité de nombreuses réflexions et débats dans le domaine de l'enseignement de la langue anglaise, une attention insuffisante a été accordée aux caractéristiques interactives caractérisant le discours des enseignants, principalement le comportement de questionnement des enseignants. Cette étude vise à déterminer dans quelle mesure les enseignants anglophones autochtones et non autochtones divergent quant aux différents types de questions qu'ils utilisent dans leurs classes. Afin d'atteindre ce but, huit classes ont été enregistrées, transcrites et analysées selon les différents types de questions dirigées par des professeurs d'anglais en étant leur langue maternelle et d'autres dont l'anglais ne représente pas la langue maternelle au niveau du département d'anglais de l'école nationale supérieure à ConstantineAlgérie. L'analyse des résultats révèle que l'enseignant de langue maternelle est plus enclin à promouvoir une véritable interaction en classe en employant des questions de procédure et de référence, ainsi qu'un recours étendu aux vérifications de la compréhension, alors que l'enseignant non autochtone avait tendance à favoriser la participation des élèves en utilisant abondamment les questions d'affichage et convergence, combinées à une demande abondante de clarification et de vérification de confirmation.

Mots clés: Interaction en classe, discours de l'enseignant, stratégies de questionnement, enseignants autochtones, non autochtones.

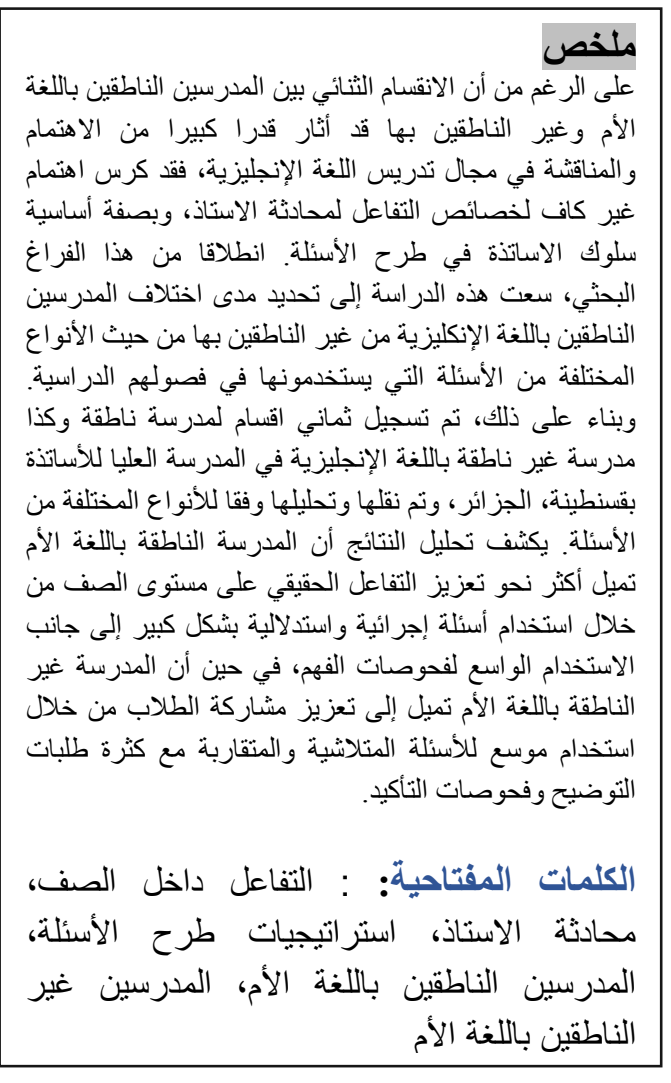

* Corresponding author, e-mail: fhadjeris@gmail.com 


\section{I- Introduction :}

Whether native speaking (NS) or non-native speaking (NNS) language teachers make better teachers is often viewed as an equivocal issue, stimulating both scholarly attention and intense debate. Medgyes (1996), for instance, acknowledged its complexity by highlighting the significant properties which characterize NS from NNS teachers; the fact which makes the choice between both types misleading, in Medgyes' own words: "what is a weakness on one side of the coin is an asset on the other" (p.39). Subsequently, two different poles come into being : (a) scholars who opted for an analysis of the teaching practice of non-native speaking teachers as their focal point to uncover the potential challenges and offer recommendations for a better pedagogy, and (b) those who believe that casting light on the teaching practice of native speaking teachers is of paramount importance due to its contribution to the improvement of teaching. The second pole, in turn, led to the birth of a new ideology in the field of English Language Teaching (ELT) called "native-speakerism", which prioritized native speaking teachers over non-native speaking teachers on the grounds that the former belong to 'Western culture' from which stem the ideals of both the English language and its teaching methodology (Holliday 2005, as cited in Holliday 2006).

To cast light on this issue, we opted for an observation of the actual performance of both types of teachers in their classes along with an analysis of their talk; an area which has not been widely researched. Probably, a comprehensive analysis of teacher talk is an ambitious goal to be achieved in this paper due to the existence of multiple features which characterize it, mainly the amount and type of teacher talk, types of questions, types of error correction and speech modifications made by teachers when addressing second language learners (Nunan, 1990). Accordingly, this study focuses exclusively on teachers' questioning behavior for various reasons. First, questioning plays a significant role since there is no classroom interaction without elicitation techniques which occupy the first position in Sinclair and Coulthard's (1975) tripartite initiation-response-feedback (IRF) exchange and the second position in Bellack's et al. (1966) system comprised of four moves: Structure, solicit, respond and react. Second, achieving a successful classroom interaction is grounded on a creative way of stimulating learners' response. Third, teachers' questioning behavior is even more highlighted in language classes, because language is considered as the medium of instruction and the goal to be achieved. This study, therefore, investigated questioning strategies employed by Native speaking teachers (NSTs) and Non-native speaking teachers (NNSTs) in EFL classes. More specifically, it seeks to find out whether there is any divergence between NSTs and NNSTs in terms of the types and frequency of questions employed in their EFL classes and, if there is any, to describe it.

\section{II- Review of the Literature:}

\section{The Native Vs. Non-native EFL Teacher Dichotomy}

Medgyes (1996), among other scholars, stressed the importance of drawing a line between native and non-native speaking teachers due to its significant contribution to the field of pedagogy. Based on his enquiry in this topic, he clearly states: "I shall argue that the native/ non-native distinction not only exists, but that it plays a key role in determining the teaching practice of all teachers" (p.35).

Before settling on the discussion of NSTs Vs. NNSTs, it is worth devoting a space to define the term 'native speaker'. Being initially used by Bloomfield (1933), it refers to somebody who has spoken a certain language since his/ her early childhood (McArthur,1992). From another standpoint, a native speaker is viewed as a person who has a subconscious knowledge of rules and inventiveness in language use; hence, he/ she masters the language without being able to articulate his/ her knowledge. Further, he/she is able to create unlimited number of sentences which he/ she has never been 
exposed to before (Cook, 2008). These privileges make the native speaker the main source of reference to be consulted by any L2 or FL learner (Davies, 2003).

For more clarification, Davies (2013) pinpointed six properties that distinguish a native speaker of the language from a non-native speaker. First of all, in line with Mc Arthur's (1992) definition, the acquisition of L1 for which he/ she is a native speaker takes place in the childhood. Second, the native speaker holds intuitions in terms of appropriateness and constructiveness about his/her "idiolectal" grammar. To elaborate on this, Brown (2008) described an idiolect as somebody's personal language. Hence, an idiolectal grammar refers to the speaker's unique knowledge of grammatical rules and structures. Third, when it comes to standard language grammar, the native speaker has intuitions about the features which are distinct from his/ her idiolectal grammar. Moreover, the native speaker shows a wide range of communicative competence in terms of comprehension and production of the target language accompanied with a unique capacity to write creatively. Finally, he/she has a unique capacity to translate into $\mathrm{L} 1$ for which he/she is a native speaker.

Davies' (2013) definition seems to be conflicting with the "native" assumption stated above. According to Bloomfield (1933), somebody can be a "native" speaker because they were born using only English - and any variety of it. Hence, if the same person never learned a "standard" version of English, he/she would not be considered a "native" speaker. So, from Davies' standpoint, what is meant by "native" means to use a certain variety of a language, one that is valued and privileged.

Considering the abovementioned privileges, would it be safe to put native speaking teachers in a better position than the non-native ones? Cook (2008) agrees on the advantage shared by all native speakers which is speaking the target language as L1; hence, the proficiency that foreign language learners are striving to achieve. She notes: "the native speaker can model the language the students are aiming at and can provide an instant authoritative answer to any language question. Their advantage is indeed the obvious one that they speak the language as a first language" (p.186).

This claim, however, appears to be problematic as it represents a misconception of bi/multilingualism, as Grosjean (1989) stated, a bilingual is not two monolinguals in one. In other words, it is unrealistic and unfair to expect bi/multilinguals to use the target language in all of the same ways and with the same proficiency as someone who has only used that target language (a monolingual).

Despite what has been stated in favor of the native speaking teachers, Cook (2008) herself disagrees that a native speaker is the best choice for teaching their native language. According to her, if both NSTs and NNSTs are given equal training opportunities, the only advantage that native speakers would have is their proficiency in the target language or in Cook's own words: "the native speaker's advantage is their proficiency in their native language, no more, no less" (2008, p.187). Therefore, being a native speaker does not necessarily mean that he/she is a good teacher, because the only gain is his/ her mastery of the target language. Conversely, there are qualities which are only idiosyncratic to the non-native speaker, mainly benefiting from local training, being acquainted with the local culture and having the skill to talk about grammar of the target language.

Likewise, Cook (2008) acknowledges being proficient in the target language as a substantial advantage associated with native speaking teachers. That being said, this kind of proficiency could be one reason which intimidates students who will likely consider it a perfection that is out of their reach. Eventually, they find it more preferable to be taught by a "fallible" NNS teacher whom they would perceive as a more achievable model. It is worth noting here that Cook's definition of proficiency is relative. In other words, what point do we say a person is proficient and who gets to make that determination is still vague.

To delve into the drawbacks associated with NS teachers, Medgyes (1996) highlighted a number of points which he drew from a comparative study of NS and NNS teachers of English. First of all, although NS teachers make perfect language models, they cannot act as learner models, simply because they are not learners of English in the sense that NNS teachers are. Second, by acquiring the English language, 
NS teachers have not adopted or employed any learning strategy; hence, they cannot teach learning strategies effectively as can NNS teachers do. Third, although NS teachers are proficient users of the language, they cannot provide learners with more information about the language which NNS abundantly gained during their learning experience. Moreover, NS teachers cannot expect learners' language problems; hence, they will not be able to help their students to overcome language difficulties or avoid pitfalls. Alternatively, experiencing different difficulties during the learning process makes NNS teachers more sensitive and empathetic to the needs and problems of learners. Last but not least, since NS teachers are not proficient in learners' mother tongue, they are deprived from a very effective vehicle of communication in the language classroom which can simplify the teaching/learning process in myriad ways (p.39-40).

\section{Classroom Interaction and Questioning Behavior}

Classroom interaction has been widely acknowledged by researchers to play a prominent role in language learning. Hence, the investigation of what is going on in classroom discourse and what roles are played by teachers and learners come to the fore. For Richards \& Lockhart (1996), interaction is the core of second language learning because a great deal of time in teaching is devoted both to interaction between teacher and learners or among the learners themselves. Walsh (2011), for instance, maintains that "interaction underpins everything that takes place in a classroom" (p.137). Interestingly, Van Lier (1988) holds that any endeavor for the measurement of students' learning should probably be based on classroom interaction as a point of reference. He puts it:

Learning as a process and as a result, may not be overtly signaled in ways that are observable by a researcher who does not intervene in the interaction. If we want to find out how and why learning does or does not take place in specific classroom settings, we need information from a variety of sources, once of them being classroom interaction (p.91, emphasis in original).

Although the study of the inextricable relationship between classroom interaction and learning is a worthwhile topic that would have a lasting impact in the domain of Second Language Acquisition, the study classroom interaction per se requires time and efforts. Therefore, a more effective approach would be deconstructing the broad term "classroom interaction" and putting one's focus on the elements which shape or rather initiate this interaction. In this respect, the issue of questioning in EFL classes comes to the fore.

In fact, teachers adopt different techniques to elicit students' responses and to stimulate active communication within their classes, be it a subject or a language class. That being said, the importance of teachers' questioning behavior is even more highlighted in language classes simply because the language is both the object to conduct the instruction and the goal that needs to be achieved. To back up this claim, Long \& Sato (1983) alluded to the mutual relationship which exists between questioning and SLA stating that: "teachers' questioning behavior is probably one of the subset of classroom process variables related to the phenomenon whose understanding is our ultimate goal, classroom SLA" (p.269, italics in original). The authors went further to add that the functions of teachers' questions should be assigned a considerable value in "foreigner talk discourse" because they contribute to sustaining non-native speakers' participation in various ways. According to them, "questions can help make greater quantities of linguistic input comprehensible, and also offer a NNS interlocutor more speaking opportunities" (p.270).

Likewise, Ellis (2008) argued that research on questioning behavior is based on the assumption that L2 learning will be enhanced if teachers' questions result in an active learner participation and meaning negotiation. To put it in another way, teachers' questions might affect L2 acquisition if they are used appropriately to push learners' 
output. In the same vein, Brumfit \& Mitchell (1989) pointed to the prominent role played by questions in sustaining students' contribution by either participating in or modifying classroom discourse. Hence, if used properly, questioning will eventually trigger more comprehensible and personally relevant language.

Interesting enough, Hyman (1989) believes that the role played by questioning in classroom talk is unique due to two main reasons. In addition to being a prerequisite for classroom instruction, the different questions that teachers ask serve to stimulate students' thinking process. Hayman (1989) declares:

The question-answer dyad is central to the thinking process and is therefore, essential to effective teaching. Indeed, it is impossible to conceive of a teaching situation in which questions by the teacher and the students are not asked and answered. When teachers teach, they talk; when they talk, they ask their students questions to stimulate thinking (p.73).

\section{Types of Questions}

Research in the area of SLA demonstrated that teachers employ a variety of questions in their language classes, which certainly requires specific criteria for their classification. According to Ellis (2008), the main standard used by researchers in this classification is the role played by questions in classroom interaction; hence, the fact which could only be understood in relation to the goals that teachers are trying to achieve. In what follows, types of questions are delineated according to three different classifications provided by Richard \& Lockhart (1996), Long \& Sato (1983) and Walsh $\& \operatorname{Li}(2016)$

\subsection{Richard \& Lockhart's Classification}

\subsubsection{Convergent Questions}

Convergent questions are used with the aim of encouraging students' responses which focus on a central theme. These responses are generally embodied in short answers such as 'yes', 'no', or short statements. As reflected in the name, this type of questions does not usually require students to engage in higher level thinking in order to come up with a response; rather, they often focus on the need of previously presented information. A rapid sequence of convergent questions is often asked by language teachers to help develop aural skills and vocabulary along with encouraging whole-class participation prior to shifting to another teaching technique (Richard \& Lockhart, 1996).

\subsubsection{Divergent Questions}

Unlike convergent questions, divergent questions encourage diverse responses from students which are not short answers; rather, they require students to engage in higher- level thinking. The ultimate aim of this type of questions is to encourage students to provide their own information rather than on recalling previously presented material.

Richards \& Lockhart (1996) maintain that both convergent and divergent questions are designed for a shared set of aims, which mainly include engaging students in the content of the lesson, facilitating their comprehension and promoting classroom interaction.

\subsubsection{Procedural Questions}

Unlike questions which are associated with the content of learning, procedural questions are related to classroom procedures, routines and management. Richards \& Lockhart (1996) maintain that procedural questions are used by the teacher for a variety of reasons such as clarifying instructions for a task, checking the completion of assignments and checking students' readiness for the new task.

\subsection{Long \& Sato's (1983) Classification}

\subsubsection{Confirmation Checks}

They are more frequent in the speech of teachers when information is conveyed by students. In such sub-category of questions, there is exact or semantic, complete or partial repetition of the previous speaker's utterance. They are either yes/ no or uninverted (rising intonation) questions in which a yes answer is presupposed. 
Confirmation checks serve the function of eliciting confirmation that the user had heard and / or understood the previous speaker's previous utterance correctly or to eliminate that belief (Long \& Sato, 1983).

\subsubsection{Comprehension Checks}

They are defined as expressions used by native speakers with the aim of finding out whether that speaker preceding utterance has been understood by the interlocutor. This sub-category of questions is characterized by the use of tag questions, repetition of all or part of the same speaker's preceding utterance with rising intonation, or by utterance like "do you understand?" to explicitly check comprehension by the interlocutor (Long \& Sato, 1983).

\subsubsection{Clarification Requests}

They are those expressions used by native speakers to elicit clarification of the interlocutor preceding utterance. They generally consist of yes/ no or wh-questions as well as uninverted and tag questions. Hence, they require the interlocutor either to supply new information or to recode the information that has been previously given. Unlike confirmation checks, clarification requests do not imply presupposition on the speaker's part that he/ she has heard and understood the interlocutor's previous utterance (Long \& Sato, 1983).

\subsection{Walsh \& Li's Classification (2016)}

\subsubsection{Referential questions}

Walsh \& Li (2016) defined referential questions as more open-ended and genuine questions whose answers are unknown to the teacher. According to them, they are posed "to promote discussion and debate, engage learners and produce longer, more complex responses which carry actual meaning". As a result, they stimulate more 'natural' responses by learners, often extended and more complicated, and contribute to generating a more conversational type of interaction (p.491).

\subsubsection{Display Questions}

Unlike the previous type, display questions are those questions whose answers are already known by the teacher. According to Walsh \& Li (2016, p.490), the name 'display questions' is adopted because they ask learners to display what they already know. More specifically, they are designed to check or evaluate their understanding, concepts, listening and previous learning. Unlike referential questions, Chaudron (1988) assumed that display questions tend to be closed, but they are more likely to promote more meaningful communication between the teacher and learners.

\section{Questioning in Native Vs. Non-Native English-Speaking Teachers' Classes}

Kayaoğlu (2013) led a case study into classroom questions employed by a native and a non-native speaking teacher in EFL classes in Tukey. Two classes of sophomore students took part in the study: the first class taught by a local teacher and the second taught by a native-English teacher. Classroom interaction has been audio recorded, transcribed, and then analyzed by focusing on questions used by both native and non-native teachers according to the taxonomies of Long \& Sato (1983) and Richards \& Lockhart (1996). The results of the study reveal that both teachers make use of different types of questions in their instruction with the aim of promoting divergent thinking and developing higher cognitive processing. Regarding Richards and Lockhart's taxonomy, it has been noticed that the non-native speaker did not employ procedural questions, but the/ she used more divergent questions than the native teacher. Concerning Long and Sato's taxonomy, it has been observed that while the non-native speaker employed referential questions much more than the native speaker teacher, the latter shows preference towards the use of display questions which elicit responses already known by the teacher. Moreover, according to Long and Sato's taxonomy of clarification requests, confirmation checks and comprehension checks, the researcher's results reveal that the non-native speaker teacher opted for clarification 
requests and confirmation checks in order to encourage students to paraphrase wrong utterances. Meanwhile, comprehension checks are used by the native speaker teacher at least three times more than the non-native speaker teacher.

Torr (1993 as cited in Gibbons, 2006) conducted a similar study including ESL primary classroom teachers from both native and non-native English-speaking background; yet, his findings are quite different from Kayaoğlu's in terms of teachers' use of display and referential questions. The non-English speaking background teachers tend to speak more frequently, contribute more to the construction of discourse and ask fewer questions which mainly require display responses (naming people, things or processes). By comparison, questions asked by teachers from English speaking background involve more illustration about how and why something occurs.

\section{III- Methods and Materials:}

\section{Setting and Sample}

Two classes of a native and a non-native EFL teacher at the department of English at Constantine Teachers' College, Algeria, have been observed. The first class comprises 30 second year students (28 females and 2 males) taking oral expression course. The class meets two times a week, and it is taught by a female, American teacher in her fifties who is the only native speaking teacher available to take part in the study. She came from USA to Algeria on a one-year contract as a language fellow within a program sponsored by the Department of State. The participant has an experience of eleven years in teaching EFL.

The native speaking teacher is compared with an Algerian non-native speaking teacher at the same college who has been selected on the basis of the classes and subject taught by the native speaking teacher. Therefore, an equivalent class of oral expression with second year level taught by a non-native speaking teacher took part in the study. The participant is an Algerian female in her forties who has an experience of ten years in teaching EFL. The class comprises 30 students (26 females and 4 males).

All the students are joining the college to get a licensure to teach English either at the middle school or at the high school level. They are also Algerians who came from different states in the eastern part of Algeria. Their ages range from 18 to 20, and they have studied English for about eight years before joining Teachers' college.

Table. 1

Participants Background Information

\begin{tabular}{|l|l|l|l|l|l|c|}
\hline Participant & Gender & Age & $\begin{array}{l}\text { Ethnic } \\
\text { group }\end{array}$ & $\begin{array}{l}\text { Mother } \\
\text { tongue }\end{array}$ & $\begin{array}{l}\text { Target } \\
\text { language }\end{array}$ & $\begin{array}{l}\text { Experience in } \\
\text { teaching EFL }\end{array}$ \\
\hline Teacher 1 & Female & $50 \mathrm{~s}$ & American & English & English & 11 years \\
\hline Teacher 2 & Female & $40 \mathrm{~s}$ & Algerian & Arabic & English & 10 Years \\
\hline
\end{tabular}

\section{Data Collection and Analysis}

A total of 8 sessions have been audio-recorded with the two observed teachers during the academic year 2018-2019. Based on a personal communication with Dr. Darer, a senior lecturer of Spanish at Wellesley college, who conducted a research on Social and Pedagogical Processes in Spanish as a Second Language Classrooms, published in 1996 at the University of Florida, we have been advised to record different classes and choose just a sample of tapes randomly to avoid any doubt pertaining to the presence of the researcher in the class. Therefore, two audio-tapes which belong to the two observed teachers are selected randomly. The audio-recordings are transcribed by 
using Express Scribe transcription software, and then analyzed according to the different types of questions used by teachers.

\section{IV- Results and discussion :}

The overall analysis of data reveals that both native and non-native speaking teachers of EFL employ several questioning strategies in their classroom oral discourse, although some types are likely to be used more frequently than others. The different types of questions and how they are used by the observed teachers will thoroughly be discussed below.

Table 2 .

Types of Questions in EFL Classes (Richard \& Lockhart, 1996)

\begin{tabular}{llrrrrrr}
\hline & \multicolumn{2}{l}{$\begin{array}{l}\text { Procedural } \\
\text { Questions }\end{array}$} & \multicolumn{2}{l}{$\begin{array}{l}\text { Convergent } \\
\text { Questions }\end{array}$} & \multicolumn{2}{l}{$\begin{array}{l}\text { Divergent } \\
\text { Questions }\end{array}$} & Total \\
\cline { 2 - 8 } & $\mathbf{N}$ & $\%$ & $\mathrm{~N}$ & $\%$ & $\mathrm{~N}$ & $\%$ & \\
\cline { 2 - 8 } Native speaker & 42 & 58.33 & 13 & 18.05 & 17 & 23.61 & 72 \\
Non-native speaker & 4 & 6.66 & 41 & 68.33 & 15 & 25 & 60 \\
\hline
\end{tabular}

As demonstrated in table 2, there is an extensive use of procedural questions $(58.33 \%)$ by the NEST compared to NNEST $(6.66 \%)$, which could be justified by the role she assigns to herself in the class. As a mediator of classroom interaction, the NEST devotes much time to reviewing classroom procedures since most of classroom talk and activities are done by learners. Besides, she is so strict about time allocated to in class activities; hence, she consistently checks students' accomplishment of these activities which could be another justification for the increased number of this type of questions. Moreover, while there is an almost equivalent use of divergent questions by both NEST and NNEST, the latter tends to employ more convergent questions than the former. This brings us to the conclusion that the NNEST focuses more on promoting vocabulary and aural skills and encouraging whole-class participation rather than engaging students in higher level thinking (Richards \& Lockhart, 1996).

The obtained results, to some extent, align with the findings of Kayaoğlu (2013) in the Turkish context, especially in terms of the integration of the first and the second type of questions. Throughout his comparative study, Kayaoğlu (2013) concluded that the use of procedural questions by the NEST (30\%) exceeds that of the NNEST who has not employed any procedural question in his/her class. Similarly, NNEST uses more convergent questions $(33.3 \%)$ compared to the NNEST $(20 \%)$.

Table 3.

Question types in EFL Classes (Walsh \& Li, 2016)

\begin{tabular}{llllll}
\hline & \multicolumn{2}{l}{$\begin{array}{l}\text { Referential } \\
\text { Questions }\end{array}$} & \multicolumn{2}{l}{$\begin{array}{l}\text { Display } \\
\text { Questions }\end{array}$} & Total \\
\cline { 2 - 6 } & $\mathrm{N}$ & $\%$ & $\mathrm{~N}$ & $\%$ & \\
\cline { 2 - 6 } Native speaker & 23 & 63.88 & 13 & 36.11 & 36 \\
Non-native speaker & 22 & 44.89 & 27 & 55.10 & 49 \\
\hline
\end{tabular}


The results indicate that while the NEST uses more referential questions than the NNEST, the latter shows preference toward using display questions which elicit answers already known by the teacher. These findings confirm the fact that the NEST has a tendency towards promoting classroom discussion and debate by integrating questions that stimulate learners' productivity (Chaudron, 1988), whereas the NNEST gives priority to display questions as her main objective is to encourage meaningful classroom communication (Chaudron, 1988). Surprisingly, these results are not analogous to the findings obtained by Kayaoğlu (2013); rather, they are completely the opposite as the NNEST uses more referential questions than the NEST and vice versa regarding the use of display questions.

Table 4.

Question types in EFL Classes (Long \& Sato, 1983)

\begin{tabular}{|c|c|c|c|c|c|c|c|}
\hline & \multicolumn{2}{|c|}{$\begin{array}{l}\text { Clarificatio } \\
\text { n } \\
\text { Requests }\end{array}$} & \multicolumn{2}{|c|}{$\begin{array}{l}\text { Confirmatio } \\
\text { n } \\
\text { Checks }\end{array}$} & \multicolumn{2}{|c|}{$\begin{array}{l}\text { Comprehensio } \\
\text { n Checks }\end{array}$} & \multirow[t]{2}{*}{ Total } \\
\hline & $\mathbf{N}$ & $\%$ & $\mathbf{N}$ & $\%$ & $\mathbf{N}$ & $\%$ & \\
\hline & 1 & 1 & 12 & 12 & 87 & 87 & 100 \\
\hline 1 von-mative speaner & 21 & 36.20 & 25 & 43.10 & 12 & 20.68 & 58 \\
\hline
\end{tabular}

As indicated in table 4, the most noticeable finding is the NEST extensive use of comprehension checks at least three times more than the NNEST. Meanwhile, the latter has a tendency toward using more clarification requests and confirmation checks as a strategy to encourage students to modify erroneous utterances (Kayaoğlu, 2013). On the contrary, the NEST rarely uses confirmation checks and totally neglects the use of clarification requests. These results align with the findings of Kayaoğlu (2013) vis-àvis confirmation checks and comprehension checks but there is no resemblance regarding the use of clarification requests.

It should be noted that the overall analysis of data in both language classes also reveals that while the native EFL teacher tends to make a lot of intra-turn pauses, the non-native speaking teacher is more likely to repeat the same question more than one time as a strategy to elicit more answers from students. As illustrated in excerpt 1 , the NNEST is observed to have an attitude of a constant repetition of the same question to elicit more responses from learners in line 455 and 457 respectively.

\section{Excerpt 1}

$454 \mathrm{~L}$ : I think the if Ireland decides to stay with the European union it will be the same except for the borders the pass and it would only remain with the goods with the trade

$455 \mathrm{~T}$ : ahah so is sorry is Ireland part of Britain? (0.3) is Ireland part of Britain?

456 LL: No

$457 \mathrm{~T}$ : no (0.8) we made a distinction between Britain and uh

457 Is Ireland part of Britain?

458 L: northern Britain Ireland is uh 
459 T: it is northern Ireland we are not talking about southern Ireland is totally independent we are talking about northern Ireland

459 Is it part of Britain?

460 L: no

$462 \mathrm{~T}$ : You have said that it's part of?

463 L: it's part of the United Kingdom

464 T: it's part of UK it's part o::f [UK what's the difference between UK and Britain? display

465 LL:

$[\mathrm{UK}$

(NNEST, $2^{\text {nd }}$ year class)

Another interesting and worth mentioning observation taken from native speaking teacher class is her frequent use of a new type of questions which is not cited in the literature. In addition to the abovementioned types, namely procedural, convergent and divergent questions ( Richard \& Lockhart, 2007), display and referential questions ( Walsh \& Li, 2016) along with the three types of questions used for meaning negotiation, i.e., clarification requests, confirmation checks and comprehension checks ( Long \& Sato, 1983), there are other types of questions which are neither related to the content of the lesson nor to classroom procedures or meaning negotiation. Rather, they are questions which are employed by the Native speaking teacher with the aim of checking students' attitudes, point of view, or feeling toward a specific activity. Excerpt 2 demonstrates this point.

\section{Excerpt 2}

138 T: Okay? You want a pair for pros and for cons or do you guys think that just your partner will tell you?

139 L: no no just a partner will tell me

140 T: special points just special points.

140 does everybody understand what are you doing?

141 LL: ((unintelligible))

$142 \mathrm{~T}$ : Does everybody understand what are you doing?

143 LL: yes

144 T: okay

(NEST, $2^{\text {nd }}$ year)

As illustrated in line 138, the NEST posed the question to make sure that the students feel comfortable with the groups they are making to accomplish the assigned task. After students' response, the teacher respected their choice and proceeded with asking confirmation checks in line140 and 142. 


\section{IV-Conclusion:}

This study is an exploration into native Vs. non-native English-speaking teacher talk in terms of the different elicitation techniques employed in EFL classes. To achieve this end, classroom interaction of a native and a non-native EFL speaking teachers was recorded, transcribed and then analyzed according to the three taxonomies of questions offered by Long \& Sato (1983), Richards \& Lockhart (1996) and Walsh \& Li (2016). The results divulge significant differences between the NEST and the NNEST in terms of the use of different types of questions. First of all, the NEST employs more procedural questions than the NNEST which could be justified by the teachers' tendency to promote students' autonomy. Second, although there is no significant difference between both teachers in terms of the use of divergent questions, the NNEST has a tendency towards promoting students' participation throughout an extensive use of convergent questions compared to the NEST. Third, whereas the NEST uses more referential questions than the NNEST, the latter shows preference toward using display questions which elicit answers already known by the teacher. In terms of meaning negotiation, the NEST opted for an extensive use of comprehension checks at the expense of confirmation checks and clarification requests which are either barely used or neglected, however the NNEST has a tendency toward using more clarification requests and confirmation checks. Last but not least, an interesting observation which sprung out from the analysis of the NEST is the integration of a new type of questions which has psychological effects rather than pedagogical ones. This type which I would call "attitudinal" or "psychological" questions is frequently posed with the aim of checking students' attitudes, point of view, or feeling toward a specific activity.

Based on the results of the investigation, teachers should bear in mind that questioning, as one of the most important aspects of teacher talk, has a great impact on students' thinking skills, contribution to classroom activities and production of the target language. Therefore, they are recommended to work toward generating successful and genuine classroom interaction based on effective questioning strategies which would promote rather than hinder second language acquisition.

\section{Referrals and References:}

[1] McArthur, T. (ed.) (1992) The Oxford Companion to the English Language. Oxford: Oxford University Press.

[2] Brown, T. L. F. (2008). Delivering the sermon: Voice, body, and animation in proclamation. Minneapolis, MN: Fortress Press.

[3] Brumfit, C., \& and Mitchell, R. (1989). Research in the Language classroom. London: Modern English in association with the British Council

[4] Chaudron, G. (1988). Second language classrooms: research on teaching and learning. Cambridge: Cambridge university press.

[5] Cook, V. (2008). Second language learning and language teaching (4 ${ }^{\text {th }}$ Ed.). UK: Hoddereducation.

[6] Davies, A. (2003). The Native Speaker: Myth and Reality. UK: Multilingual Matters Ltd.

[7] Davies, A. (2013). Native Speakers and Native Users: Loss and Gain. Cambridge: Cambridge

University Press.

[8] Ellis, R. (2008). The Study of Second Language Acquisition (2nd ed.). Oxford, UK: Oxford University Press 
[9] Gibbons, P. (2006). Bridging Discourses in ESL Classrooms. Students, Teachers and researchers. New York: continuum

[10] Holliday, A. (2006). Native-speakerism. Volume 60, Issue 4. ELT Journal, Pp. 385-387. Doi: 10.1093/elt/cc1030

[11] Hyman, T. R. (1989). Questioning in the College Classroom. In Neff, R. A. \& Weimer, M. (Edts.). Classroom Communication: Collected Readings for Effective Discussion and Questioning. Madison, Wisconsin: Magna publications, Inc.

[12] Kayaoğlu, N, M., (2013). Case Study into the Classroom Questions by a Native Speaker and a Non-Native Speaker Teacher in EFL Classes. The Asian EFL Journal Professional Teaching Aticles, 69.

[13] Long, M., \& Sato, C. (1983). Classroom Foreigner Talk Discourse: Forms and Functions of Teachers' Questions. In H. Seliger, \& M. Long (Eds.), ClassroomOriented Research in Second Language Acquisition (pp. 268-286). Rowley, MA: Newsbury House.

[14] Medgyes, p. (1996). Native or non-native: who is worth more? in Hedge and Whitney (eds), power, pedagogy and practice (pp.31-42). Oxford: Oxford University press

[15] Nunan, D. (1990). Second Language Classroom Research. ERIC Digest. ERIC Clearinghouse on Languages and Linguistics Washington DC.

[16] Richards, J. C. \& Lockhart, C. (1996). Reflective Teaching in Second Language Classrooms. Cambridge: Cambridge university press.

[17] Sinclair, J. M. \& Coulthard, R. M. (1975). Towards an Analysis of Discourse: The English Used by Teachers and Pupils. London: Oxford University Press.

[18] Tsui, A. B.M. (2011). Classroom discourse. In Simpson, J. (Ed.), The Routledge Handbook of Applied Linguistics (pp274-286). New York: Routledge.

[19] Van Lier, L. (1988). The Classroom and the Language Learner: Ethnography and Second Language Classroom Research. New York: Longman Inc.

[20] Walsh, S., (2006). Investigating Classroom Discourse. London and New York: Routledge.

[21] Walsh, S., \& Li, L., (2016). Classroom Talk, Interaction and Collaboration (pp.486-498). In Hall, G., (Ed.), the Routledge Handbook of English Language Teaching: London \& New York: Routledge. 